\title{
地域立脚型クローバル・スタディーズ 一その成果と展望一
}

村井吉敬

\section{はじめに}

2001年末から本年 3 月末日まで、扣よそ5年半 にわたって、わたしたち上智大学チームは、文 部科学省の「21世紀COEプログラム」の中の 「学際・複合・新領域」の一拠点として活動して きた。わたしたちの拠点プログラム名は「地域 立脚型グローバル・スタディーズの構築」 (Towards Area-Based Global Studies= AGLOS）というもので、地域とグローバル化の 相互作用を実証的にあつかい、新たなグローバ ル・スタディーズの地平を切り拓くとともに、 地域研究に対してもインパクトを与えようとす るものだった。

「地域立脚型グローバル・スタディーズ」は構 築し得るのか。中間段階でプログラム委員会か ら概念そのものと、その実現性についての疑問 が投げかけられた。

わたしたちの答えはややにべないものになら ざるを得なかった。

「『グローバル・スタディーズ』とは、単にグロ ーバル化を『計測』する学問ではない。『グロー バル化』そのものも、あたかも特定の物質であ るかのように実体論的に捉えられる嫌いが一般 にあるが、交通通信技術および情報技術の進歩 によってもたらされた地球大の諸変化とそれに 由来するさまざまな影響・作用などの諸現象が 便宜的にそのように総称されているものである にすぎない。そうした影響・作用は、それぞれ
の地域が地球上で占めている地理的および政治 経済的・文化的位置にしたがい多様であり、ま たそれぞれの地域が特有の文化的視座ないし世 界認識を有している以上、たとえ作用が同じで あったとしてもその理解やそれに対する反応は 一様ではあり得ない。したがって、『グローバ ル・スタディーズ』とは、それぞれの地域にお いて表面化する現象面での諸変化の把握にとど まらず、それぞれの地域に打けるそうした諸変 化に対する理解のあり方ならびに諸変化に対す る反作用の顕れ方を視野に収め、ある地域の論 理と別の地域一支配的な地域という意味で通俗 的な『グローバル』の用語を適用できるような設 定の『地域』でもありうる一の論理との相互作用 を可視化するものである。その意味で本拠点が 措定する『グローバル・スタディーズ』は、本来 的に『地域立脚型』である。」

つまり、グローバル・スタディーズという単 一ディシプリンは、地域の立場に立つ以上あり 得ない、地域のさまざまな人間の営みや自然生 態環境からグローバル化に迫ることこそが複 合・学際分野における学の構築に他ならないと の立場であり、それはこのプログラムが終わっ た今日の時点でも言いうることであると考えて いる。欧米起源のグローバル・スタディーズを、 地域、あるいはアジア・中東・中南米などから 問い直し、鍛え上げていくのが地域立脚型グロ ーバル・スタディーズの構築に他ならないとの 立場である 


\section{地域立脚型グローバル・スタディーズ の目指したもの}

わたしたちのプログラムはつぎのようなもの である。

「地域立脚型グローバル・スタディーズとは、 政治・社会・経済・文化面でのさまざまなグ ローバルな動きと地域社会・歴史との間の相 関関係を対象とする研究・教育プログラムで す。グローバル・スタディーズそのものは欧 米を中心に近年世界各地の大学に扔いて取り 上げられていますが、AGLOSでは、特に日 本・アジアに根差しアジア・中東・ラテンア メリカなどに扣ける地域固有性を重視する立 場から、グローバルな流れを解明することを 目指します。

研究面では、およそ20名の事業推進担当者 を中心に、上智大学グローバル・スタディー ズ研究科地域研究・国際関係論・比較文化各 専攻の教員、上智大学の他の教員、また海外 拠点など他大学の研究者、大学院生・ポスド クの参加を呼びかけ、地域立脚型グローバ ル・スタディーズの構築を罒ります。具体的 には、I『グローバル化の中の政治：重層的ガ バナンス』、I『グローバル化の中の社会・経 済：市民社会と開発・交易』、III『グローバル 化の中の文化：宗教・文化の越境とアイデン ティティの動的構築』の3群で構成され、各群 の研究プロジェクトを総括しつつ研究計画を
推進し、その成果を世界に発信することを目 標としています。

大学院教育の面では、本プログラムに根差 した持続的な研究者養成を行うために、現在の 3つの専攻をグローバル・スタディーズ研究科 (仮称)へと改組することを上智大学全体の将来 構想の中で検討しています。その第一歩とし て、『グローバル・スタディーズ』関連科目を 2003年度より開講することになりました。グ ローバル・スタディーズに相応しい真にグロー バルな教育研究環境を構築するというAGLOS の特色は、海外拠点を含む国際ネットワークの 整備としても表れます。既存の海外拠点として は、11年間にわたりアンコール研修所として 実績を挙げ、2002年秋に改組・強化されたカ ンボジアのアジア人材養成研究センターをあげ ることが出来ますが、今後はフィリピン・エジ プト・メキシコ・ブラジル・中国・フランスな どに海外協力拠点の整備を進める予定です」 (AGLOSホームページhttp://www.aglos" sophia.jp/jp/index.htm1より)。

後段の制度面については、グローバル・スタ ディーズ研究科がすでに立ち上がり（2006年度 より)、とりわけ、従来の外国語学研究科比較文 化専攻は、グローバル社会専攻に衣替えをし、 抎らく日本では初めて、本格的なグローバ ル・スタディーズを目指す教育組織になってい る。従来の「地域研究専攻」も、グローバル・ス 
タディーズを視野に入れつつ、課程の再編が拘 こなわれてきている。

問題は前段の「日本・アジアに根差しアジア・ 中東・ラテンアメリカなどに扎忏地域固有性 を重視する立場から、グローバルな流れを解明 すること」という、いわば学問理論面でどれだけ の貢献ができたか、という点にある。わたした ちは当初から「グローバル・スタディーズ」は、 物理学や経済学という、既存の学問体系と同次 元の理論体系を持ちうるものだとは思っていな 加た。それはそもそも学際的な研究領域でし かあり得ないし、地域に根ざした研究が重視さ 机るべきだと考えてきた。

20 世紀末から今日まで、世界情勢は激変しつ つある。ベルリンの壁の崩壊、東西冷戦体制の 終焉、民族・宗教紛争の激化、難民の大量発生、 南北対立や南南問題の鮮明化、さらにはグロー バル経済を牽引するアメリカなど欧米諸国家へ の「テロ」攻撃など、新たに取り組むべき諸問 題が急浮上しつつある。また、世界経済全体の 市場経済化にともない、新たに賀富の格差の拡 大、環境問題、感染症など、深刻な問題を生み 出しつつある。さらに、情報革命とも呼ぶべき 情報メディアの進歩と多様化は、従来の国境を いっ号低くし、人びとの佂值観に多大な影響 を与え、これまで国家や企業が主要に形成して きた国際関係に扣いて、NGO（非政府組織）な どが主要なアクターとして登場し、国際関係を より多角的に形成し始めた。グローバル・イッ シュー（地球規模問題）といわれる、これら諸

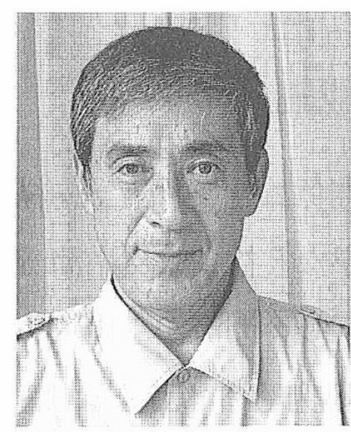

\section{PROAIL}

村井吉敬

(むらいよしのり 1943年生) 上智大学21世紀COEプログラム 拠点リーダー、上智大学大学院 グローバル・スタディーズ研究 科地域研究専攻教授 専門：社会経済学・東南アジア 社会経済論

問題などすべてを一つの理論で説明し尽くすこ とはできない。地域固有の事情を斟酌しない一 般化は信賴性を勝ち得ないであうう。

従来、日本の知的伝統はその多くを欧米に依存 し、日本の大学に打ける教育も欧米の知識導人と 消化に費やされてきた。しかし、日本は地理的に アジアの一角に位置し、アジアの一員であること は紛机もない事実であり、ボーダレス化が急速に 進展している状況を考觉ると、日本の大学に括外 るアジア、ラテンアメリカ抬よびアフリカ地域な どのいわゆる発展途上地域・非西洋世界について の、情報の掑取、知識の集積と体系化、教育内容 の充実を図っていくことが強く求められていた。 上智大学では、とりわけ、このような情勢の中 で、アジア・中東・中南米なざ、特に非西洋社会 の地域研究の必要を痛感し、80年代以降、アジ ア・中東の地域研究とその研究を制度化し、 1996年には外国語学研究科（現、グローバル。 スタディーズ研究科）の中に地域研究專攻を立ち 上げ、その専攻が母体となり、国際関係論専攻、 比較文化專攻（現、グローバル社会専攻）の協力 を得て21世紀COEの拠点を担ったのである。 


\section{AGLOSの成果}

従来型の国際関係論や、政治学、経済学、あ るいは文化人類学など社会人文系諸分野がグロ 一バル化という新しい潮流から挑戦を受けてい るように、地域研究もさまざまな挑戦を受け、 変質を余儀なくされている。AGLOSの事業推進 担当者のかなり多くが地域研究者である。国家 でいえば、中国、カンボジア、インドネシア、 フィリピン、エジプト、マグリブ諸国、コロン ビア、ブラジル、メキシコ、そして日本などを 研究対象としてきた。学問分野では政治学、経 済学、社会学、歴史学、考古学、文化人類学な ど多岐にわたる。21世紀COE助手として採用さ れたり、研究資金で調查を実施したかなりの数 の若手研究者を含め机ば、地域も学問分野もさ らに広がる。

「グローバル化」を意識し、視野にいれた膨大 な数の地域の調查研究、論考が生まれた。その 成果をここですべて紹介することはできないの で、毎年おこなわれた比較的規模の大きな国際 シンポジウム（AGLOSグローバル・スタディー ズシンポジウム）についてだけこでは簡単に 紹介して打く。

(1)「対立か収斂か：グローバル化とローカリテ $1\rfloor$ (Conflict or Convergence? Regions in a Globalizing Age）（2003.3.15-16）（問題 の設定、提起)、基調講演：サスキア・サッ セン (米国・シカゴ大学教授、社会学)

(2)「地球規模の政治社会に向かって：21世紀に
おけるグローバルな規範」(Prospects and Challenges for the World Polity: Global Norms in the Twenty-first Century（政治 面でのグローバル化）（2003.12.6-7）、基調 講演: ジョン・マイヤー（米国・スタンフォ ード大学名誉教授)

(3)「拡散する紛争と難民：グローバリゼーショ ンは地球共同体を構築しうるか」Expanding Conflictand Refugees: Can Globalization Construst a Global Community?)（社会 経済面でのグローバル化）(2004.12.4-5)、 基調講演 : 村井吉敬「開発·紛争・難民」 (上智大学)

(4)「宗教を消費する：グローバル化時代の信仰の かたち」Consuming Religion: Globalization and Popular Beliefs（文化宗教面でのグロ ーバル化）（2005.11.19-20)、基調講演 : 「宗教施設の商品化とその限界」大塚和夫 （東京外国語大学アジア・アフリカ言語文化 研究所)

これらの国際シンポジウムは、上記のように、 問題提起・枠組みの設定から始まり、政治面で のグローバル化、社会経済面でのグローバル化、 文化宗教面でのグローバル化をテーマとしてき た。特徴的なことは、上記には抢名前を出して いないが、欧米主流のグローバリゼーション理 論に対して、第三世界や日本から参加していた だいた講演者やディスカッサントの方々から、 果敢な挑戦や疑問が提起されてきたことである。 これらの議論については、AGLOS NewsのNo.1 
〜No.10に揭載されているので参考にしていた だきたい。また、若手研究者による調查研究に ついてはワーキング・ペーパーなどで公刊され ている。さらに、「地域立脚型グローバル・スタ ディーズ叢書」(第1〜巻) が本年度中に刊行 される予定（上智大学出版会）で、この中でわ たしたちの成果が網羅されることになっている。

\section{まとめにかえて} 一地域とは何かを改めて問う一

上記の4シンポジウムを締めくくる最終シンポ ジウム「『グローバル」を視る・生きる一共同体 理念再考」(Reframing the World: Globalism, Nationalism, Fundamentalism）が2006年1月 13日に開催された。最後に、グローバル化の世 界潮流を振り返る、そしてそれを担い推進する 人びと、組織について考えるというのがシンポ ジウムの趣旨であった。グローバルに対置され るものとして、国家があり、地域がある。グロ ーバル化イデオロギー（主要には新自由主義、 あるいは自由経済市場万能主義）に対峙するイ デオロギーや信念の体系なども考えられる。そ れをここでは「共同体」として言い表した。わ たしたちの独自の思いとしては、国家連合共同 体（EUなど）でも、国家でもない、言ってみれ ば自立した、国家よりも小さな「地域」を構想 してもいいかもしれない、と考えている。グロ 一バル化と、ある意味で張り合える活力ある自 立した地域、これらの地域が連合する、という
図式をわたし自身は思い浮か心゙ている。

グローバル化はどの地域でも、人びとのレべ ルでも、また組織のレベルでも一律、一様に進 められているわけではなく、それを熱狂的に進 める人もいれば、斜めに見ている人もいれば、 猛反対している人びともいる。その（グローバ ル化の）力学と、地域での対応について考えて みたのがこのシンポジウムの趣旨だった。

そこでは、グローバル化の持つ歴史的な危う さ、グローバル化そのものが、紛争や戦争につ ながっているのだとの内在的矛盾が語られ、最 終的には、人間の尊厳や倫理が語られた。グロ 一バル化を推進する政治権力構造も解明されつ つある。おそらく、わたしたちに残された大き な課題に、そもそも「地域」とは何なのか、そ してグローバル化の通常の解釈である越境は、 国家を越える動きとだけとらえられているが、 地域概念の再検討と共に、越境そのものを地域 や人びとの視点から大胆に再検討していくこと にあるのではないだろうか。 